\title{
ALZHEIMEROVA CHOROBA - RIZIKOVÉ A PROTEKTÍVNE FAKTORY
}

\author{
Ingrid Gul'ášová
}

Vysoká škola zdravotníctva a sociálnej práce sv. Alžbety v Bratislave

\section{ÚVOD}

Vo vyššom veku prirodzene nastupujú určité zmeny, ktoré sú závislé ako na genetických predispozíciách, tak na vonkajších vplyvoch, s ktorými človek behom života prichádza do kontaktu. Starnutie je súborom množstva pochodov, ktoré začínajú ovel’a skôr, než postrehneme ich prvé zjavné príznaky. Ide o dej multifaktoriálny, vznikajúci súčinnost’ou genetického základu a vonkajšieho prostredia. Fyziologické starnutie znamená, že nastávajú fyziologické zmeny kognitívnych a d'alších psychických schopností. Sú to drobné abnormality, ktoré sa vyskytujú u väčšiny zdravej populácie (Pidrman, 2007a). Proces starnutia je sprevádzaný zmenou intelektových i emocionálnych aktivít a odolnost' človeka voči stresu sa znižuje ,v dôsledku čoho aj jeho schopnost' zvládat' zát'ažové situácie klesá (Křivohlavý, 2002).

Takto možno definovat' primárne starnutie, fyziologický jav. Na starnutí sa ale môžu podiel'at' aj faktory, ktoré síce súvisia so starnutím, nemusia však nutne byt' jeho dôsledkom. Tu hovoríme o sekundárnom starnutí, ktoré je ovplyvnené zdravotným stavom, životným prostredím, je dôsledkom interakcie prostredia a životného štýlu (Hartl, Hartlová, 2004).

Alzheimerova choroba je ochorenie, pri ktorom dochádza $\mathrm{k}$ úbytku nervových buniek. $\mathrm{V}$ mozgu postihnutého vznikajú škodlivé bielkoviny. Tie sa ukladajú v podobe vlákien v okolí nervových buniek ako amyloidové plaky. Plaky a neurofibrilárne zmeny interferujú $\mathrm{s}$ prenosom elektrochemických signálov medzi neurónmi, napokon narúšajú intelekt a pamät', pričom procesy závisia od počtu, umiestnenia a vel'kosti plakov. Prichádza k poškodeniu a zániku nervových buniek a ich spojov. Zároveň v mozgovom tkanive dochádza $\mathrm{k}$ znižovaniu acetylcholínu. Túto látku potrebuje mozog $\mathrm{k}$ prenosu nervových vzruchov. Pri jeho nedostatku strácajú bunky schopnost' navzájom si vymieňat' infor- mácie. Degeneratívne zmeny na mozgu sa stupňujú a to sa prejaví postupným zhoršovaním pamät'ových a rozumových schopností, rozvija sa demencia. Vel'a zmien nastáva $v$ mozgovej kôre, čo má za následok úbytok mozgovej hmoty. V iniciálnych štádiách je atrofia najväčšia vo frontálnych a v temporálnych lalokoch. Pri pokročilej Alzheimerovej chorobe môže byt' atrofická viac ako polovica mozgovej kôry v oblasti dôležitej pre funkciu pamäti. Ďalším nálezom je úbytok enzýmu cholínacetyltransferázy a acetylcholíesterázy v kôre mozgu, v oblasti dôležitej pre funkciu pamäti. Pokles koncentrácie enzýmov vyúst'uje do porúch prenosu impulzov nervovými vláknami.

Alzheimerova demencia (AD) je získané kognitívne a behaviorálne poškodenie takého stupňa, že významne interferuje so spoločenským a profesijným fungovaním postihnutého jedinca. Z hladiska obvyklého nástupu ochorenia môžeme hovorit' o tzv. presenilnej alebo skorej forme $\mathrm{AD}$, kedy sa ochorenie rozvinie ešte pred 65 rokom života jedinca. V zriedkavých prípadoch genetického pôvodu sa môže začat' už vo veku 35 rokov. Druhou formou je Alzheimerova choroba s neskorým začiatkom, teda s nástupom ochorenia po 65 roku veku života. Výskyt choroby v populácí sa zvyšuje s vekom (do 65 rokov je to $1,5 \%$, po 80 rokoch až $20 \%$ ). To je aj vysvetlenie, prečo v našich priemyselných spoločnostiach výskyt rastie paralelne so zvyšujúcim sa počtom osôb starších ako 65 rokov (Turčáni, 2001). Pidrman (2007b) uvádza riziko rozvoja demencie $\mathrm{v}$ súvislosti s vekom nasledovne: do 65 rokov veku - $5 \%$, do 75 rokov - $10 \%$, do 80 rokov - $20 \%, 90$ rokov - $50 \%$ populácie je postihnutej demenciou.

Alzheimerova choroba má do istej miery individuálny priebeh i dobu prežívania. Postihnutí prežívajú od dvoch do dvadsat' rokov, v priemere najčastejšie od osem do desat' rokov. 
Presné príčiny Alzheimerovej choroby zatial' nepoznáme. S určitost'ou možno povedat' iba to, že sa jedná o neurodegeneratívne ochorenie neznámej etiológie, ale s niektorými preukázatel’nými rizikovými faktormi. Na jednej strate sú to zdedené vlastnosti metabolizmu, podmienené geneticky, na druhej strane vplyvy prostredia a životného štýlu (SAS, 2005). Callone a kol. (2008) vymedzujú tri základné oblasti poškodenia u l'udí s demenciou: kognitívne poruchy, behaviorálne a psychologické poruchy a funkčné poruchy.

Včasná diagnostika AD je pre d'alší vývoj ochorenia vel'mi dôležitá, nakol'ko čím skôr sa zaháji liečba, tým väčšia šanca je na spomalenie a zmiernenie jej priebehu a tým na zlepšenie kvality života chorého. Diagnostika AD prebieha na základe jednak laboratórnych, jednak klinických vyšetrení, ktoré pomôžu lekárovi stanovit' diagnózu $\mathrm{AD}$ s vysokou pravdepodobnost'ou. Zist'uje sa stupeň postihnutia kognitívnych a nonkognitívnych funkcií (schopnost' zapamätat' si nové veci a vybavit' si ich, schopnost' logického uvažovania, evidentné bývajú poruchy tzv. symbolických funkcií ako výpadky pomenovaní bežných predmetov dennej potreby, neschopnost' používat' obvyklé nástroje). Iné testy zist'ujú zasa samostatnost' pri bežných denných úkonoch a pri sebaobsluhe (ADL, IADL). Na pomoc prichádzajú aj laboratórne vyšetrenia, resp. CT, MR (Príručka, 2005).

Vedci hl'adajú faktory, ktoré sa zdajú byt' spojené s rozvojom ochorenia. Ide o tzv. „rizikové faktory“ - tam, kde sú prítomné, je väčšia pravdepodobnost' - nie však istota - že sa choroba vyvinie. Rizikové faktory sú jednak osobné predispozície človeka, jeho životný štýl, prostredie a genetické pozadie, ktoré prispievajú $\mathrm{k}$ vyššej pravdepodobnosti, že osoba začne trpiet' AD. Niektoré rizikové faktory je možné sledovat' a životosprávou či medikamentózne upravit' (napr. zníženie krvného tlaku); iné upravit' nemožno (napr. genetickú výbavu danej osoby). Je dôležité si uvedomit', že rizikové faktory nie sú samy o sebe príćinou ochorenia. Všeobecne sa vedci domnievajú, že Alzheimerova choroba je spôsobená kombináciou viacerých vplyvov rôznych rizikových faktorov, ktoré, ked' prekročia určitú hranicu, prekonajú prirodzené samoregulačné a opravné mechanizmy mozgu a rozvinie sa ochorenie. Identifikácia rizikových faktorov pre Alzheimerovu chorobu je dôležitá, lebo dáva možnost' úpravou životného štýlu znížit' riziko prepuknutia ochorenia u danej osoby. Niektoré faktory sú mimo kontroly jednotlivcov, zatial' čo iné významné rizikové faktory možno znížit' vhodným životným štýlom (Clarke et al., 2000).

Ciel'om tejto práce je podat' informácie o rizikových faktoroch, ktoré môžu viest' k nástupu Alzheimerovej demencie a zároveň upozornit' na tzv. protektívne faktory, ktoré naopak vedú $\mathrm{k}$ predchádzaniu ochoreniu, resp. odd'al'ujú jeho nástup a na istý čas spomalia priebeh ochorenia.

Pri Alzheimerovej demencii prvým a najmarkantnejším príznakom býva úbytok kognitívnych funkcií, ako prvá býva poškodená krátkodobá pamät' (Hort, Rusina et al., 2007). Spôsob, ako dochádza k vzniku kognitívneho deficitu, je rôzny a zvyčajne ide o vplyv biologickej zát'aže, genetických daností osobnosti, ale aj patologického vývoja osobnosti (Höschl et al., 2002).

\section{Charakteristika rizikových faktorov}

\section{Vek}

Za najväčší známy rizikový faktor pre vznik Alzheimerovej choroby sa považuje vek. Hoci existuje skorá forma ochorenia začínajúca ešte pred 65. rokom veku života, výskyt Alzheimerovej choroby pred 65. rokom veku života je vzácny. S pribúdajúcim vekom obyvatel'stva sa jej výskyt v populácií zvyšuje. Pravdepodobnost' vzniku Alzheimerovej choroby sa zdvojnásobuje približne každých pät' rokov. Najčastejšie AD začína vo veku 65 až 74 rokov, po 85. roku veku života riziko dosahuje takmer $50 \%$. Nie je však jasné, či rizikovým faktorom je vek samotný, alebo fakt, že vo vyššom veku sa môže pridat' pôsobenie d’alších vplyvov. Niekedy sa uvádza, že Alzheimerova choroba je vlastne neprirodzené starnutie mozgu. Nad 80 rokov už chorobou trpí každý piaty človek. Zriedkavý je výskyt Alzheimerovej demencie so skorým nástupom, zvyčajne medzi 45. a 65. rokom života (Turčáni, 2001).

\section{Pohlavie}

Alzheimerova choroba postihuje o niečo častejšie ženy ako mužov. Môžu za to pravdepodobne rozdiely $\mathrm{v}$ hladinách hormónov, najmä pokles estrogénu u žien v menopauze. Avšak hormonálne zmeny nie sú jediným faktorom, ktorý 
prispieva k zvýšenému výskytu Alzheimerovej choroby u žien. V priemere ženy žijú dlhšie ako muži a vek je rizikový faktor. Ženy sú viac náchylné $\mathrm{k}$ diabetu, ktorý je tiež rizikovým faktorom. V poslednej dobe bol identifikovaný gén, ktorý sa vyskytuje len u žien, a zdá sa, že mierne zvyšuje riziko vzniku Alzheimerovej choroby (Príručka, 2005).

\section{Genetika}

Alzheimerova choroba môže byt' dedičná. Pravdepodobne existujú gény, ktoré zvyšujú riziko rozvoja Alzheimerovej choroby. Vel'mi malé percento l'udí s Alzheimerovou chorobou má tzv. Familiárnu Alzheimerovu chorobu alebo FAD (predtým známy ako „skorý nástup Alzheimerovej choroby $\left.{ }^{\circ}\right)$. Túto dedičnú formu treba odlíšit’ od častejšej sporadickej formy AD, avšak vonkajšie prejavy ochorenia sú totožné. U sporadickej formy Alzheimerovej choroby (AD s neskorým nástupom) sa pôvodne predpokladalo, že nemá žiadne rodinné väzby a nejde teda o multigeneračný postih. Avšak dnes je známe, že osoba s výskytom AD u priamych príbuzných (rodičia, súrodenci) má podstatne väčšiu pravdepodobnost', že u nej ochorenie prepukne, ako tá, ktorá v príbuzenstve Alzheimerovu chorobu nemá (Szaboó, 2006).

\section{ApoE4 Gen}

Tento gén je najdôležitejším genetickým rizikovým faktorom pre sporadické formy Alzheimerovej choroby. Tieto gény regulujú produkciu proteínu, ktorý pomáha niest' hladinu cholesterolu a iných tukov $\mathrm{v}$ krvi. Z troch variantov génu je variant apoE4 spojený so zvýšeným rizikom Alzheimerovej choroby. $\mathrm{V}$ našich bunkách (okrem vajíčka a spermie) sú všetky gény spárované, pričom jeden je vždy od otca, druhý od matky. Ak jeden zo spárovaných génov je ApoE4 gén, je riziko vzniku Alzheimerovej choroby vyššie. U približne polovice všetkých l'udí s dvoma ApoE4 génmi sa rozvinie Alzheimerova choroba vo veku do 65 rokov. U l'udí bez ApoE4 génu môže prepuknút' Alzheimerova choroba, a osoby s dvoma ApoE4 nemusia nevyhnutne ochoriet' (Turčáni, 2001).

\section{Nízky stupeň vzdelania}

Učenie vyžaduje zvýšenie aktivity mozgu. Zdá sa, že mozog ,trénovaný“ je voči chorobe odolnejší. Chránit’ nás preto môže trvalá duševná aktivita (čítanie, lúštenie krížoviek, záujem o kultúru). Niekol'ko štúdií ukázalo, že l’udia, ktorí majú menej ako šest' rokov formálneho vzdelania, majú vyššie riziko vzniku Alzheimerovej choroby. Predpokladá sa teda, že stimulácia mozgu spojená s učením poskytuje mozgu ochranný účinok, a preto d’alšie vzdelávanie poskytuje väčšiu ochranu. Avšak nová štúdia svedčí proti tomuto záveru a je možné, že faktory často spojené s nízkym dosiahnutým vzdelaním, ako je napríklad nezdravý životný štýl, predstavujú väčšie zdravotné riziko ako nízke vzdelanie samotné (Klevetová, Dlabalová, 2008).

\section{Opakované úrazy hlavy}

Ťažké alebo opakované úrazy hlavy môžu zvýšit' pravdepodobnost' rozvoja demencie. Známy je častý výskyt demencie u športovcov, ktorí utrpeli viackrát úraz hlavy $\mathrm{s}$ bezvedomím (boxeri).

\section{Vysoký krvný tlak, vysoké hladiny tukov a cukrovka}

$\mathrm{V}$ posledných rokoch bolo zistené, že tieto ochorenia, obzvlášt' ak nie sú riadne liečené, sú rizikovými faktormi nielen pre infarkt srdcového svalu a mozgovú príhodu, ale i pre rozvoj Alzheimerovej demencie.

\section{Kardiovaskulárne ochorenia}

Všetky rizikové faktory kardiovaskulárnych ochorení (napr. vysoký krvný tlak a vysoká hladina cholesterolu) sú taktiež rizikovými faktormi pre ochorenie na Alzheimerovu demenciu (Turčáni, 2001).

\section{Diabetes}

Má vplyv na energetický metabolizmus mozgu a spôsobuje cievne a zápalové zmeny, ktoré ovplyvňujú nervový systém. Samotný inzulín zohráva úlohu pri pamät’ových funkciách. Enzým degradujúci inzulín v mozgu odbúrava zároveň aj amyloid beta (ak je $\mathrm{v}$ obehu privel'a inzulínu, kapacita enzýmu nestačí a amyloid sa môže hromadit' (Novak, 2010).

Je dobre známe, že diabetes druhého typu (,pre dospelých“) je rizikovým faktorom pre Alzheimerovu chorobu, zvlášt’ ak je prepojený s kardiovaskulárnym ochorením. Bolo zistené, že využitie glukózy v mozgu je u ludí s Alzheimerovou chorobou narušené, trochu sa podobá situácii $\mathrm{v}$ orgánoch l'udí $\mathrm{s}$ diabetom 2. typu. 
U l'udí s Alzheimerovou chorobou sa koncentrácia inzulínu v mozgu znižuje a nervové bunky sú na toto citlivé. Lieky proti diabetu, ktoré sa zameriavajú na mozog, sú teraz testované u l’udí s Alzheimerovou chorobou. U l'udí, ktorí trpia diabetom 1. typu, vyvíjajúcim sa už v detskom veku, je neskorší nástup Alzheimerovej choroby častejší než u zdravých jedincov (SAS, 2010b).

\section{Downov syndróm}

Takmer u všetkých jedincov s Downovým syndrómom, ktorí sa dožijú štyridsiateho roku veku a viac, sa vyvíjajú abnormálne zmeny v mozgu (plakety a spleti), ktoré sú charakteristické pre Alzheimerovu chorobu. Je však dôležité povedat', že nie u všetkých l’udí s Downovým syndrómom sa musí vyvinút' Alzheimerova choroba. Zdá sa pravdepodobné, že u týchto l’udí sa môžu vyvíjat' vekovo podmienené zmeny, ktoré sa vyskytujú u väčšiny l’udí s Alzheimerovou chorobou.

\section{Fajčenie a nezdravý životný štýl}

Štúdie potvrdili, že chronické fajčenie tabaku zvyšuje riziko vzniku AD. Zásadný negatívny vplyv má okrem vrodených faktorov aj nezdravý životný štýl a nevhodné stravovanie. Nedostatok pohybu, stres, prejedanie sa, nedostatok zeleniny a ovocia $v$ strave sú výrazným rizikovým faktorom. Ochorenie vzniká komplikovanou súhrou viacerých okolností. Všetky uvedené riziká zrejme len pripravujú vhodnú pôdu pre zatial' neznámy spúšt'ač choroby. Ten spôsobuje poruchy zodpovedné za zmeny v mozgu.

Vedecká verejnost' najviac prikladá význam nasledujúcim faktorom spôsobujúcim nástup ochorenia:

- toxické vplyvy prostredia - hromadenie hliníka, medi, zinku v mozgu;

- vírusové infekcie - retrovírusy;

- poruchy imunitného systému.

U starších l'udí sa niekedy vyskytujú poruchy spánku s občasnými nočným dezorientáciami, výrazná afektívna labilita, depresie a podozrievavost' voči okoliu môže prerást' až do paranoidného syndrómu. Tieto symptómy môžu predchádzat' prvým príznakom v kognitívnej oblasti aj o niekol'ko rokov pred diagnostikovaním Alzheimerovej demencie. Často sa považujú za príznak bežného starnutia, je však treba venovat' im pozornost' a podl'a potreby ich liečit', pretože to môžu, i ked' nemusia, byt' varovné signály blížiaceho sa nástupu ochorenia. Včasným rozpoznaním a zachytením príznakov môžeme prispiet' $\mathrm{k}$ predĺženiu kvalitného života postihnutého a tým aj jeho okolia (SAS, 2010a).

\section{Protektívne faktory}

Za protektívne faktory sa naopak považuje vyššie vzdelanie, vyššia psychická aktivita, mentálny tréning, užívanie antiflogistík, hormonálna substitúcia u žien po menopauze, včasná a účinná liečba depresií a neklesajúca psychická aktivita vo vyššom veku (Príručka, 2008).

Demenciu Alzheimerovho typu v súčasnosti možno liečit', i ked' kauzálna liečba a vyliečenie zatial' možne nie je, liečba je len symptomatická. Ciel'om liečby demencie je predovšetkým, aby bola účinná, zároveň však je potrebné brat' do úvahy bezpečnost' takejto liečby pre pacienta a to, do akej miery je liečba dobre znášaná. Vzhl'adom na predpoklad dlhodobej liečby je nezanedbatel'ný aj faktor vekových farmakoterapeutických limitov a obmedzení. Antialzheimerikami $\mathrm{v}$ súčasnosti terapeuticky ovplyvňujeme iba jednotlivé články patologického procesu s následným spomalením progresie kognitívnej deteriorácie so zretel'om na zlepšenie fungovania na úrovni vykonávania ADL a MMSE testov ako aj zmiernením prejavov ochorenia. Detailnejšie poznávanie jednotlivých čiastkových procesov v patogenéze Alzheimerovej choroby na subcelulárnej úrovni poskytuje množstvo hypotéz o tom, čo je dominantným pri spustení kaskády zmien vedúcich k typickým morfologickým zmenám mozgu a $\mathrm{v}$ konečnom dôsledku $\mathrm{k}$ demencii. $\mathrm{V}$ súčasnosti ešte neexistuje ucelená a všeobecne prijatá hypotéza. Napriek intenzívnej práci pri vývoji nových liekov v blízkej budúcnosti nie je možne očakávat' prevratne zmeny v liečbe Alzheimerovej choroby ani d'alších typov demencií (Žigová, 2006).

Liečebné programy využívajú predovšetkým behaviorálnu a kognitívnu formu terapie. Táto zahŕňa udržiavanie, obnovu a znovuučenie sa zručností súvisiacich so sebaobsluhou, vrátane komunikatívnych zručností. Od liečby sa všeobecne očakáva oddialenie progresie ochorenia, stabilizácia chorého, predíženie doby sebestačnosti a funkčných schopností chorého (Hátlová et al., 2010). Ciel’om liečby je teda predovšetkým ovplyvnenie kognitívnych funkcií, emočnej reaktivity, správania prostredníctvom spoluúčasti na zmysluplnej činnosti a prežívania seba samého 
ako platného člena spoločenstva, potrebného pre ostatných. Hlavným zmyslom je tu tendencia kvalitu života udržiavat' a stabilizovat'. Dôležité je udržanie chorého čo najdlhšie v sociálnej sieti, v ktorej je vhodná sociálna podpora. Vieme, že Alzheimerovu chorobu nedokážeme vyliečit', naším ciel'om ale musí byt' zlepšenie kvality života chorých, ich opatrovatel'ov a d'alších ich blízkych (Ressner, 2004).

Alzheimerova demencia je ochorenie, ktorého základným znakom je trvalá progresia. Len zriedka sa podarí zlepšit' funkčné a kognitívne výkony pacienta. Za liečebný úspech je považovaný pokles na škále MMSE o menej ako 3 body za rok. Pred začatím akéhokol'vek terapeutického pôsobenia je bezpodmienečne nutné poznat' nielen somatický stav chorého s jeho špecifikami a pravdepodobným smerovaním vývoja, ale aj stav jeho psychiky a psychických, sociálnych a duchovných potrieb. Vyšetrenie chorého vyžaduje vysokú mieru empatie a často aj niekol'ko stretnutí nutných $\mathrm{k}$ tomu, aby $\mathrm{v}$ terapeutovi našiel chorý toho, komu môže dôverovat', toho, kto ho neohrozuje, toho, kto je schopný a ochotný mu pomôct'. Po získaní dôvery chorého je možné počítat's jeho účast'ou na terapií podl'a jeho aktuálneho nastavenia.

Liečba demencie by mala byt' komplexná a mala by byt' konzultovaná $\mathrm{v}$ multidisciplinárnom tíme. $\mathrm{K}$ úspechu liečby významne prispieva dobré rodinné zázemie chorého a čo najdlhšie zotrvanie v domácom prostredí. Buijssen (2006) odporúča pre získanie informácií o tom, čo chorý prežíva, využit' tieto tri zdroje informácií:

1. Verbálne, slovné alebo písomné oznámenia chorého (chorý potrebuje dlhší čas na formulovanie svojich zážitkov, potrieb a priani). Niekedy sa uplatňuje formu listu, poznámok a pod.

2. Pozorovanie správania chorého (spracovávanie bežných podnetov života a vol’ba pre chorého zvládnutel'ných foriem správania).

3. Vlastná schopnost' vžit' sa do situácie chorého, následne ju hodnotit' a volit' zodpovedajúce neohrozujúce postupy.

Počet pacientov s diagnózou Alzheimerovej demencie $\mathrm{v}$ populácií neustále narastá a je predpoklad, že súčasne s nárastom počtu starších občanov $\mathrm{v}$ populácií sa aj počet takto postihnutých občanov bude zvyšovat'. Ochorenie na demenciu závažne ovplyvnuje ako postihnutého samotného, tak aj rodinných príslušníkov a jeho okolie a stáva sa tak výrazným sociálnospoločenským problémom. Napriek tomu, že výskumu Alzheimerovej demencie a možnostiam jej ovplyvnenia sa ostatných rokoch venuje stále väčšia pozornost', doposial' neexistuje príčinná liečba ochorenia, ktorá by bola schopná Alzheimerovu demenciu vyliečit' alebo priebeh ochorenia zvrátit'. Dostupné antialzheimeriká môžu postup ochorenia na istú dobu pozastavit', môžu dokonca mierne zlepšit' kognitívne funkcie pacienta, ale po istom čase choroba d'alej progreduje až do neodvratného konca.

$\mathrm{V}$ prístupe $\mathrm{k}$ ochoreniu stále väčší význam nadobúda behaviorálna intervencia, ktorá v sebe zahŕňa nefarmakologické prístupy liečby ako sociálno-aktivizačné cvičenia zamerané na pohybovú koncentráciu, ergoterapia, arteterapia, muzikoterapia, aromaterapia, tanečná terapia, petterapia a kognitívna rehabilitácia.

Potrebnou súčast'ou starostlivosti je aj podpora rodinných príslušníkov a opatrovatel'ov chorého, ktorí často nechápu správne podstatu ochorenia a jeho prejavy. Jednou zo služieb poskytovaných osobám, ktoré opatrujú osobu s Alzheimerovou chorobou, je tzv. „odl'ahčovacia“ alebo respritná služba. Jej ciel’om je umožnit' opatrovatel'om dostatočný čas na zregenerovanie svojich psychických a fyzických síl (Máhrová a kol., 2008).

Preto vznikajú aj na Slovensku podporné organizácie a skupiny, ktoré pomáhajú rodinám s chorým na Alzheimerovu demenciu, ale aj profesionálnym opatrovatel'om oboznámit' sa s priebehom ochorenia a jeho úskaliami tak, aby boli schopní viest' plnohodnotný život a pritom čo najviac predížit' samostatný a aktívny život postihnutého človeka, o ktorého sa starajú.

\section{LITERATÚRA}

1. Buijssen H (2006). Demence. 1. vydání. Praha: Portál, $132 \mathrm{p}$.

2. Callone RP a kol. (2008). Alzheimerova nemoc. Praha: Grada Publishing, $120 \mathrm{p}$.

3. Clarke PJ, Marshall V, Ryff CD, Rosenthal CJ (2000). Well-being in Canadian Seniors. Findings from the Canadian Study of Health and Aging. Canadian Journal on Aging [online] 19/2: 139-159. [cit.2010-02-11]. Dostupné z: http://muse.jhu.edu/ journals/cja/

4. Hartl P, Hartlová H (2004). Psychologický slovník. 1. vydání. (opravený dotisk) Praha: Portál, 776 p.

5. Hátlová B et al. (2010). Psychomotorická terapie demencií v počáteční a střední fázi. Oddělení aktivit v prírode, o. s. \& Asociace psychologů sportu. 80 p. 
6. Hort J, Rusina R. et al. (2007). Pamět' a její poruchy. Praha: Maxdorf, $422 \mathrm{p}$.

7. Höschl C et al. (2002). Psychiatrie. Praha: Tigris, 883 p.

8. Klevetová D, Dlabalová I (2008). Motivační prvky při práci se seniory. Praha: Grada, 202 p.

9. Křivohlavý J (2002). Psychologie nemoci. 1. vydání. Praha: Grada Publishing, 200 p.

10. Máhrová G a kol. (2008). Sociální práce s lidmi s duševním onemocněním. Praha: Grada Publishing, p. 176.

11. Novak M (2010). Útok Alzheimerovej choroby na našu pamät'. Prednáška, Bratislava: CVTI SR, [online]. [cit. 2010-10-23]. Dostupné z: https:// www.vedatechnika.sk/SK/VedaASpolocnost/ NCPVaT/Stranky/Utok-Alzheimerovej-choroby-nanasu-pamat.aspx

12. Pidrman V (2007a). Demence. Praha: Grada Publishing, p. 192.

13. Pidrman V (2007b). Psychiatrie seniorů. Aug, 2007. In: Česká a slovenská psychiatria, Praha: Nakl. a tisk. stredisko České lékařské spol. JEP, p. 27.

14. Príručka (2005). Alzheimerova choroba a ako ju zvládnut' v domácom prostredí. Pomoc opatrovatel'om. Autor neuvedený. 3. vydanie. Bratislava: SAS, $46 \mathrm{p}$.
15. Príručka (2008). Autor neuvedený. Neuroimunologické centrum pre výskum Alzheimerovej choroby, Bratislava, p. 17

16. Ressner P (2004). Alzheimerova choroba - diagnostika a léčba. Neurologie pro praxi. [online]. 1: 1116. [cit.2010-05-14]. Dostupné z: http:// www.neurologiepropraxi.cz/magno/neu/2004/ mn1.php

17. SAS (2010a). Pomoc opatrovatel'om (Alzheimerova choroba - ako ju zvládnut' $\mathrm{v}$ domácom prostredí) [online]. [cit.2010-10-20]. Dostupné z: http:// www.alzheimer.sk/informacie/publikacie.aspx

18. SAS (2010b). Rizikové faktory Alzheimerovej choroby. SAS, 2010. [online]. [cit.2010-02-12]. Dostupné z: http://www.alzheimer.sk/informacie/ alzheimerova-choroba/o-alzheimerovejchorobe.aspx

19. Szaboó R (2006). 100 rokov od začiatku histórie Alzheimerovej choroby. Lekárske listy. Bratislava: Sanoma, 22: 21 .

20. Turčáni P (2001). Alzheimerova choroba. Neuroscience, Bratislava: Pfizer, p. 27

21. Žigová E (2006). Liečba Alzheimerovej demencie memantínom. Psychiatrie pro praxi. Olomouc: Solen, s. r. o., 6: 291-294.

Ingrid Gul'ášová edukojs@gmalil.com 